\title{
Kekuatan Sumber Daya (Ekonomi, lingkungan dan Sosial) dan Penganuhnya terhadap SDM Petemak dan Kelembagaan Petemak Sapi Perah
}

\section{(Strength of Resources (Ec onomic al, environmental, dan social) and their Impact on Farmer Human Resorces and Institutions of Dairy Cattle Famers)}

\author{
Amam, Roni Y, Wildan JM, Pradiptya AH \\ Program Studi Peternakan, Fakultas Pertanian, Universitas Jember, Jember 68121 \\ amam.faperta@unej.ac.id
}

\begin{abstract}
The livestock farming of business resources are a potential value possessed by farmers for their livestock farming business. These resources consist of resources that can be measured and which cannot be measured, so that based on their nature, resources change according to their conditions. This research aims to examine the strength of the resources of dairy cattle farming business and find its influences on HR and institutional dairy farmers. Research variables consist of economical resources $\left(\mathrm{X}_{1}\right)$, environmental resources $\left(\mathrm{X}_{2}\right)$, social resources $\left(\mathrm{X}_{3}\right)$, human resources $\left(\mathrm{Z}_{1}\right)$, and institutional dairy farmers $\left(\mathrm{Y}_{1}\right)$. The research was conducted at KUB (Joint Business Group) Tirtasari Kresna Gemilang, Malang District. Data analysis using PLS (Partial Least Square) method. The results showed that economical resources have a significant positive effect on the institutions of dairy farmers at 0.306 , but environmental resources have a significant negative effect on the institutions of dairy farmers at -0.266 . Social resources have a significant negative effect HR of dairy farmers at -0.319 , but have a significant positive effect on institutional dairy farmers. The conclusion of this research is that human resources are influenced by economical, environmental and social resources by $18.9 \%$, and institutional of dairy cattle farmers are influenced by economical, environmental, social, and human resources by $20.6 \%$.
\end{abstract}

Key words: Resources, human resources, and institutional dairy farmers

\begin{abstract}
ABSTRAK
Sumber daya usaha ternak merupakan suatu nilai potensi yang dimiliki oleh peternak untuk usaha ternaknya. Sumber daya tersebut terdiri dari sumber daya yang dapat diukur dan yang tidak dapat diukur, sehingga berdasarkan sifatnya sumber daya dapat berubah sesuai dengan kondisinya. Penelitian ini bertujuan untuk mengkaji kekuatan sumber daya usaha ternak sapi perah dan menemukan pengaruhnya terhadap SDM dan kelembagaan peternak sapi perah. Variabel penelitian terdiri dari sumber daya ekonomi $\left(\mathrm{X}_{1}\right)$, sumber daya lingkungan $\left(\mathrm{X}_{2}\right)$, sumber daya sosial $\left(\mathrm{X}_{3}\right)$, sumber daya manusia $\left(\mathrm{Z}_{1}\right)$, dan kelembagaan peternak sapi perah $\left(\mathrm{Y}_{1}\right)$. Penelitian dilakukan di KUB (Kelompok Usaha Bersama) Tirtasari Kresna Gemilang Kabupaten Malang. Analisis data menggunkana metode PLS (Partial Least Square). Hasil penelitian menunjukkan bahwa sumber daya ekonomi berpengaruh positif signifikan terhadap kelembagaan peternak sapi perah sebesar 0,306, namun sumber daya lingkungan berpengaruh negatif signifikan terhadap kelembagaan peternak sapi perah sebesar $-0,266$. Sumber daya sosial berpengaruh negatif signifikan terhadap SDM peternak sapi perah sebesar -0,319, namun berpengaruh positif signifikan terhadap kelembagaan peternak sapi perah. Kesimpulan penelitian ini yaitu SDM peternak dipengaruhi oleh sumber daya ekonomi,
\end{abstract}


lingkungan, dan sosial sebesar 18,9\%, dan kelembagaan peternak sapi perah dipengaruhi oleh sumber daya ekonomi, lingkungan, sosial dan SDM sebesar 20,6\%.

Kata kunci: Sumber daya, SDM, kelembagaan peternak sapi perah

\section{PENDAHULUAN}

Peraturan Pemerintah Republik Indonesia Nomor 6 Tahun 2013 tentang Pemberdayaan Peternak menyebutkan bahwa pemberdayaan peternak adalah segala upaya yang dilakukan oleh pemerintah, pemerintah provinsi, pemerintah kabupaten/kota, dan pemangku kepentingan di bidang peternakan dan kesehatan hewan untuk meningkatkan kemandirian, memberikan kemudahan dan kemajuan usaha, serta meningkatkan daya saing dan kesejahteraan peternak. Kelembagaan peternak merupakan salah satu wujud dan proses pemberdayaan peternak.

Kelembagaan peternak terdiri dari kelembagaan nirlaba dan kelembagaan usaha. Kelembagaan nirlaba misalnya asosiasi, sedangkan kelembagaan usaha misalnya kelompok peternak, gabungan kelompok peternak, dan badan usaha milik peternak. Amam \& Soetriono (2019) menyebutkan bahwa kelembagaan peternak mempunyai peran dalam hal tindakan preventif peternak untuk mengurangi risiko bisnis dan bertujuan untuk pengembangan usaha ternak yang mendukung kesejahteraan anggotanya.

Prasetyo \& Awaludin (2016) menyatakan bahwa selama ini kelembagaan peternak masih dipandang belum mampu menjadi sarana untuk meningkatkan adopsi teknologi dan sarana dalam bertukar informasi di dalam kelompok peternak. Hal tersebut menurut Siswoyo et al. (2013) disebabkan salah satunya oleh rendahnya pendidikan peternak dan usia yang sudah tidak produktif sehingga menghambat perkembangan usaha ternak. Amam et al. (2019a) menyatakan bahwa SDM peternak sapi perah merupakan salah satu faktor yang sangat penting yang tidak bisa dilepaskan dari suatu organisasi atau kelembagaan peternak sapi perah. Performa kelembagaan mempengaruhi SDM peternak secara positif (Amam \& Harsita 2019).

Sumber Daya Manusia (SDM) merupakan faktor penggerak kelembagaan peternak, sehingga tinggi dan rendahnya SDM secara langsung mempengaruhi kelembagaan peternak sapi perah. Amam et al. (2019a) menyebutkan bahwa akses peternak terhadap sumber daya dapat mempengaruhi SDM peternak dan sumber lain menyebutkan bahwa dinamika kelompok sapi perah dipengaruhi oleh sumber daya internal peternak sebesar 33\%. Sumber daya internal terdiri dari sumber daya finansial, sumber daya teknologi, dan sumber daya fisik (Amam et al. 2019b).

Penguatan kelembagaan membutuhkan dukungan dari banyak pihak (Wahyuni 2017), atas dasar itu penelitian ini bertujuan untuk mengkaji kekuatan sumber daya dan pengaruhnya terhadap SDM peternak dan kelembagaan peternak sapi perah. Manfaat penelitian ini sebagai wujud dari pemberdayaan peternak sesuai dengan Peraturan Pemerintah Republik Indonesia Nomor 6 Tahun 2013.

\section{MATERI DAN METODE}

Penelitian ini menggunakan pendekatan expost facto research yang dilaksanakan pada bulan Maret hingga Juni 2019 di Kelompok Usaha Bersama (KUB) Tirtasari Kresna Gemilang Kabupaten Malang Provinsi Jawa Timur. Lokasi penelitian dipilih secara sengaja (purposive) dengan pertimbangan bahwa Kabupaten Malang merupakan salah satu kawasan peternakan sapi perah nasional sesuai dengan Keputusan Menteri Pertanian Republik Indonesia Tahun 2015 Nomor 43/Kpts/PD.010/1/2015 tentang Penetapan 
Kawasan Sapi Potong, Kerbau, Kambing, Sapi Perah, Domba dan Babi Nasional. KUB Tirtasari Kresna Gemilang dipilih karena merupakan kelembagaan peternak sapi perah yang sudah memiliki Badan Hukum Nomor 0010084-AH.01.07 dan mempunyai anggota sebanyak 174 orang.

\section{Metode pengumpulan data dan penentuan responden}

Data penelitian ini dikategorikan menjadi data primer dan data sekunder. Data primer didapatkan langsung dari peternak sapi perah, sedangkan data sekunder didapatkan dari laporan bulanan KUB Tirtasari Kresna Gemilang. Pengumpulan data dilakukan dengan metode survei, observasi, dan dokumentasi. Bentuk lisan dari survei adalah wawancara, sedangkan bentuk tulisan dari survei adalah kuisioner. Metode kuisioner yang digunakan dalam penelitian ini menggunakan skala likert +1 sampai +5 , sedangkan metode wawancara dan observasi dilakukan untuk mendapatkan informasi tambahan dari peternak sapi perah. Responden dalam penelitian ini ialah peternak sapi perah anggota KUB Tirtasari Kresna Gemilang. Jumlah sampel yang digunakan sebanyak 174 orang, sehingga penentuan responden menggunakan total sampling.

\section{Variabel dan indikator penelitian}

Penelitian ini terdiri dari lima variabel laten, yaitu sumber daya ekonomi $\left(\mathrm{X}_{1}\right)$, sumber daya lingkungan $\left(\mathrm{X}_{2}\right)$, sumber daya sosial $\left(\mathrm{X}_{3}\right)$, $\operatorname{SDM}$ peternak $\left(\mathrm{Z}_{1}\right)$, dan kelembagaan peternak sapi perah $\left(\mathrm{Y}_{1}\right)$. Indikator dari lima variabel laten tersebut diuraikan pada Tabel 1 .

Tabel 1. Variabel dan indikator penelitian

\begin{tabular}{lc}
\hline \hline Sumber daya ekonomi $\left(\mathrm{X}_{1}\right)$ & Notasi \\
\hline Pendidikan formal peternak & $\mathrm{X}_{1.1}$ \\
Pendidikan nonformal peternak & $\mathrm{X}_{1.2}$ \\
Tingkat keterlibatan tenaga kerja keluarga & $\mathrm{X}_{1.3}$ \\
Status kesehatan keluarga & $\mathrm{X}_{1.4}$ \\
Status konsumsi gizi keluarga & $\mathrm{X}_{1.5}$ \\
Tingkat kenyamanan rumah tempat tinggal & $\mathrm{X}_{1.6}$ \\
Kesempatan memanfaatkan waktu luang untuk rekreasi & $\mathrm{X}_{1.7}$ \\
Tingkat kredibilitas peternak & $\mathrm{X}_{1.8}$ \\
\hline Sumber daya lingkungan $\left(\mathrm{X}_{2}\right)$ & $\mathrm{Notasi}$ \\
\hline Tingkat pencemaran udara & $\mathrm{X}_{2.1}$ \\
Tingkat pencemaran tanah & $\mathrm{X}_{2.2}$ \\
Tingkat pencemaran air & $\mathrm{X}_{2.3}$ \\
Tingkat pencemaran suara & $\mathrm{X}_{2.4}$ \\
Pemanfaatan limbah kotoran ternak untuk pupuk & $\mathrm{X}_{2.5}$ \\
Pemanfaatan limbah pertanian untuk pakan ternak & $\mathrm{X}_{2.6}$ \\
\hline
\end{tabular}


Lanjutan Tabel 1. Variabel dan indikator penelitian

\begin{tabular}{lc}
\hline Sumber Daya Sosial $\left(\mathrm{X}_{3}\right)$ & Notasi \\
\hline Peranan peternak dalam organisasi masyarakat & $\mathrm{X}_{3.1}$ \\
Hubungan kerjasama dengan peternak lain & $\mathrm{X}_{3.2}$ \\
Hubungan dengan aparat desa & $\mathrm{X}_{3.3}$ \\
Hubungan dengan petugas kesehatan ternak & $\mathrm{X}_{3.4}$ \\
Hubungan dengan dinas peternakan dan kesehatan hewan & $\mathrm{X}_{3.5}$ \\
Hubungan dengan perusahaan pakan ternak & $\mathrm{X}_{3.6}$ \\
Hubungan dengan tenaga penyuluh & $\mathrm{X}_{3.7}$ \\
Hubungan dengan lembaga keuangan & $\mathrm{X}_{3.8}$ \\
Hubungan dengan perusahaan/industri pengolahan susu & $\mathrm{X}_{3.9}$ \\
\hline SDM Peternak (Z $)$ & $\mathrm{Notasi}_{1}$ \\
\hline Pengetahuan dan keterampilan dalam usaha ternak & $\mathrm{Z}_{1.1}$ \\
Status kesehatan peternak & $\mathrm{Z}_{1.2}$ \\
Motivasi peternak & $\mathrm{Z}_{1.3}$ \\
Kemampuan peternak dalam penggunaan bahasa sehari-hari & $\mathrm{Z}_{1.4}$ \\
\hline Kelembagaan Peternak sapi perah (Y $\left.{ }_{1}\right)$ & $\mathrm{Notasi}$ \\
\hline Sarana kelompok & $\mathrm{Y}_{1.1}$ \\
Capaian tujuan kelompok & $\mathrm{Y}_{1.2}$ \\
Fungsi dan tugas kelompok & $\mathrm{Y}_{1.3}$ \\
Struktur kelompok & $\mathrm{Y}_{1.4}$ \\
Kerukunan kelompok & $\mathrm{Y}_{1.5}$ \\
Bentuk kelembagaan & $\mathrm{Y}_{1.6}$ \\
\hline
\end{tabular}

\section{Teknik analisis data}

Data dianalisis menggunakan pemodelan SEM (Structural Equation Modelling) dengan metode PLS (Partial Least Square) dengan aplikasi SmartPLS 2.0. Penggunaan metode PLS menurut Wiyono (2011) bermanfaat untuk menguji teori yang lemah dan/atau menemukan suatu teori baru. Ilustrasi pemodelan pada persamaan struktural yang menjelaskan hubungan antar-variabel dan indikator yang diuraikan pada Tabel 1 dalam model SEM PLS ditunjukkan pada Gambar 1. 


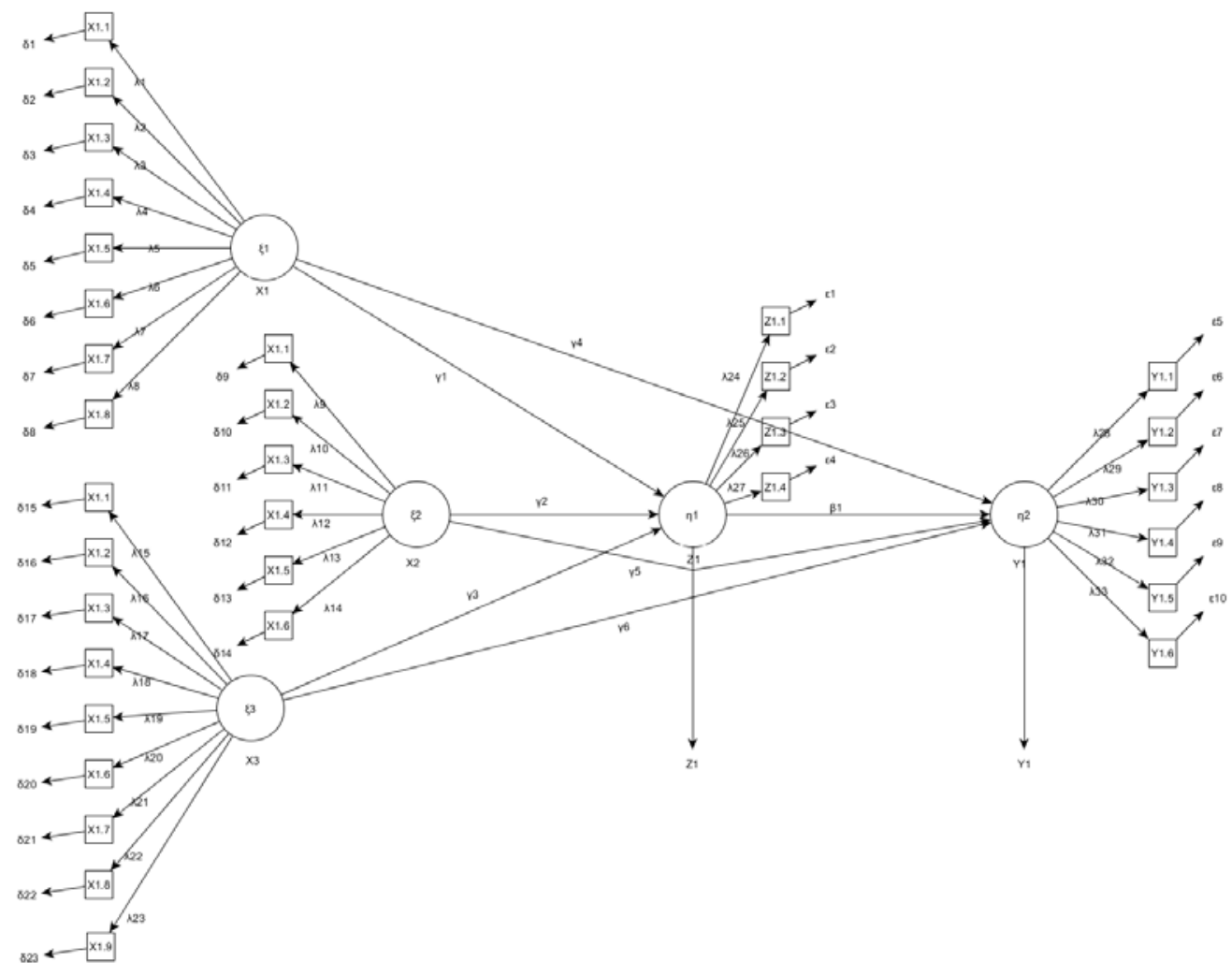

Gambar 1. Model hubungan variabel

Berdasarkan model hubungan variabel pada Gambar 1, maka hipotesis penelitian adalah: a) akses peternak terhadap sumber daya ekonomi, sumber daya lingkungan, dan sumber daya secara langsung mempengaruhi SDM peternak; b) akses peternak terhadap sumber daya ekonomi, sumber daya lingkungan, dan sumber daya sosial secara tidak langsung mempengaruhi kelembagaan peternak sapi perah melalui SDM peternak.

\section{HASIL DAN PEMBAHASAN}

Kelompok Usaha Bersama (KUB) Tirtasari Kresna Gemilang merupakan kelembagaan peternak sapi perah yang menyediakan sarana produksi ternak hingga pemasaran susu segar dengan anggota kelompok sebanyak 174 orang. KUB Tirtasari Kresna Gemilang terletak di Desa Ngabab Kecamatan Pujon Kabupaten Malang. Peternak sapi perah yang menjadi anggota KUB Tirtasari Kresna Gemilang mempunyai akses terhadap berbagai sumber daya, diantaranya sumber daya ekonomi, sumber daya lingkungan dan sumber daya sosial.

\section{Sumber daya ekonomi}

Aksesibilitas peternak sapi perah terhadap sumber daya ekonomi diantaranya: pendidikan nonformal peternak, tingkat keterlibatan tenaga kerja keluarga, tingkat kenyamanan rumah tempat tinggal, dan kesempatan memanfaatkan waktu luang untuk 
rekreasi. Hasil uji indikator (nilai outer loading) sumber daya ekonomi diuraikan pada Tabel 2 di bawah ini:

Tabel 2. Sumber daya ekonomi

\begin{tabular}{lccc}
\hline \hline Variabel & Indikator & Nilai outer loading & Keterangan \\
\hline $\mathrm{X}_{1}$ & $\mathrm{X}_{1.2}$ & 0,749 & valid \\
& $\mathrm{X}_{1.3}$ & 0,721 & valid \\
& $\mathrm{X}_{1.6}$ & 0,577 & valid \\
& $\mathrm{X}_{1.7}$ & 0,692 & valid \\
\hline
\end{tabular}

Nilai outer loading setelah mengeliminasi indikator tidak valid

Indikator sumber daya ekonomi berdasarkan hasil FGD (Focus Group Discussion) yang tidak valid dan tidak memenuhi syarat ialah indikator yang mempunyai nilai outer loading $<0,500$, sehingga harus dihilangkan (dieliminasi) dari model.

\section{Sumber daya lingkungan}

Aksesibilitas peternak sapi perah terhadap sumber daya lingkungan diantaranya: tingkat pencemaran udara, tingkat pencemaran tanah dan tingkat pencemaran suara. Hasil uji indikator (nilai outer loading) sumber daya lingkungan diuraikan pada Tabel 3.

Tabel 3. Sumber daya lingkungan

\begin{tabular}{lccc}
\hline \hline Variabel & Indikator & Nilai Outer Loading & Keterangan \\
\hline X2 & $\mathrm{X}_{2.1}$ & 0.787 & valid \\
& $\mathrm{X}_{2.2}$ & 0.614 & valid \\
& $\mathrm{X}_{2.4}$ & 0.741 & valid \\
\hline
\end{tabular}

Nilai outer loading setelah mengeliminasi indikator tidak valid

Indikator sumber daya ekonomi berdasarkan hasil FGD (Focus Group Discussion) yang tidak valid dan tidak memenuhi syarat ialah indikator yang mempunyai nilai outer loading $<0,500$, sehingga harus dihilangkan (dieliminasi) dari model.

\section{Sumber daya sosial}

Aksesibilitas peternak sapi perah terhadap sumber daya sosial diantaranya: peranan peternak dalam organisasi masyarakat, hubungan kerjasama dengan peternak lain, hubungan dengan aparat desa, hubungan dengan petugas kesehatan ternak, hubungan dengan dinas peternakan dan kesehatan hewan, hubungan dengan lembaga keuangan, dan hubungan dengan perusahaan/industri pengolahan susu. Hasil uji indikator (nilai outer loading) sumber daya sosial diuraikan pada Tabel 4 di bawah ini: 
Tabel 4. Sumber daya sosial

\begin{tabular}{llcc}
\hline \hline Variabel & Indikator & Nilai Outer Loading & Keterangan \\
\hline $\mathrm{X}_{3}$ & $\mathrm{X}_{3.1}$ & 0.677 & valid \\
& $\mathrm{X}_{3.2}$ & 0.814 & valid \\
& $\mathrm{X}_{3.3}$ & 0.808 & valid \\
& $\mathrm{X}_{3.4}$ & 0.671 & valid \\
& $\mathrm{X}_{3.5}$ & 0.715 & valid \\
& $\mathrm{X}_{3.8}$ & 0.594 & valid \\
& $\mathrm{X}_{3.9}$ & 0.520 & valid \\
\hline
\end{tabular}

Nilai outer loading setelah mengeliminasi indikator tidak valid

Indikator sumber daya ekonomi berdasarkan hasil FGD (Focus Group Discussion) yang tidak valid dan tidak memenuhi syarat ialah indikator yang mempunyai nilai outer loading $<0,500$, sehingga harus dihilangkan (dieliminasi) dari model.

\section{Pengujian outer model}

Kriteria pengujian outer model dengan menggunakan metode PLS (Partial Least Square) terdiri dari nilai AVE (Average Variance Extracted), nilai CR (Composite Reliability), nilai R Square $\left(\mathrm{R}^{2}\right)$, nilai CA (Cronbach's Alpha), nilai communality, dan nilai redudancy. Hasil pengujian terhadap berbagai kriteria tersebut ditunjukkan pada Tabel 5 dan Gambar 2.

Tabel 5. Kriteria pengujian outer model

\begin{tabular}{lllllll}
\hline \hline Variabel & AVE & CR & $\mathrm{R}^{2}$ & CA & communality & redudancy \\
\hline X1 & 0,541 & 0,757 & & 0,678 & 0,541 & \\
X2 & 0,615 & 0,759 & & 0,632 & 0,615 & \\
X3 & 0,540 & 0,860 & & 0,814 & 0,540 & \\
Z1 & 0,669 & 0,851 & 0,100 & 0,743 & 0,742 & 0,189 \\
Y1 & 0,742 & 0,839 & 0,418 & 0,755 & 0,669 & 0,206 \\
\hline
\end{tabular}




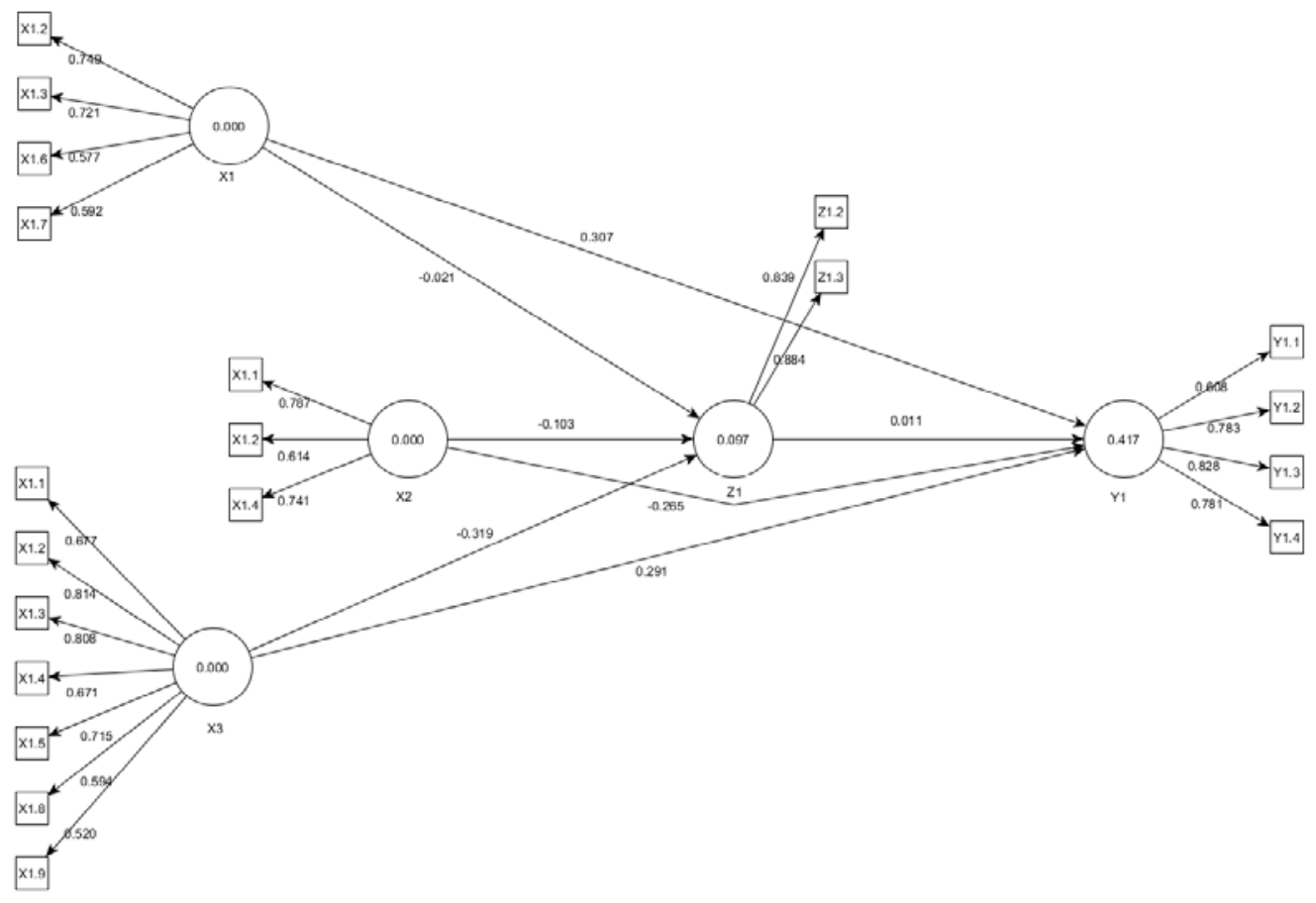

Gambar 2. Hasil logaritma PLS

\section{Pengujian inner model}

Pengujian hipotesis atau uji model struktural dilakukan setelah model yang diestimasi dan terbentuk memenuhi syarat dan kriteria pengujian outer model. Pengujian inner model terdiri dari original sample dan nilai t statistik. Hasil uji model struktural dengan menggunakan metode PLS (Partial Least Square) ditunjukkan pada Tabel 6 dan Gambar 3.

Tabel 6. Hasil uji struktural

\begin{tabular}{lccc}
\hline \hline Uji Pengaruh & Original sample & t statistik & Keterangan \\
\hline $\mathrm{X} 1 \rightarrow \mathrm{Z} 1$ & $-0,021$ & 0,135 & tidak signifikan \\
$\mathrm{X} 2 \rightarrow \mathrm{Z} 1$ & $-0,103$ & 0,694 & tidak signifikan \\
$\mathrm{X} 3 \rightarrow \mathrm{Z} 1$ & $-0,319$ & 2,224 & signifikan \\
$\mathrm{X} 1 \rightarrow \mathrm{Y} 1$ & 0,306 & 3,311 & signifikan \\
$\mathrm{X} 2 \rightarrow \mathrm{Y} 1$ & $-0,266$ & 3,027 & signifikan \\
$\mathrm{X} 3 \rightarrow \mathrm{Y} 1$ & 0,287 & 2,717 & signifikan \\
$\mathrm{Z} 1 \rightarrow \mathrm{Y} 1$ & 0,011 & 0,141 & tidak signifikan \\
\hline
\end{tabular}

Nilai t tabel adalah 1,653 


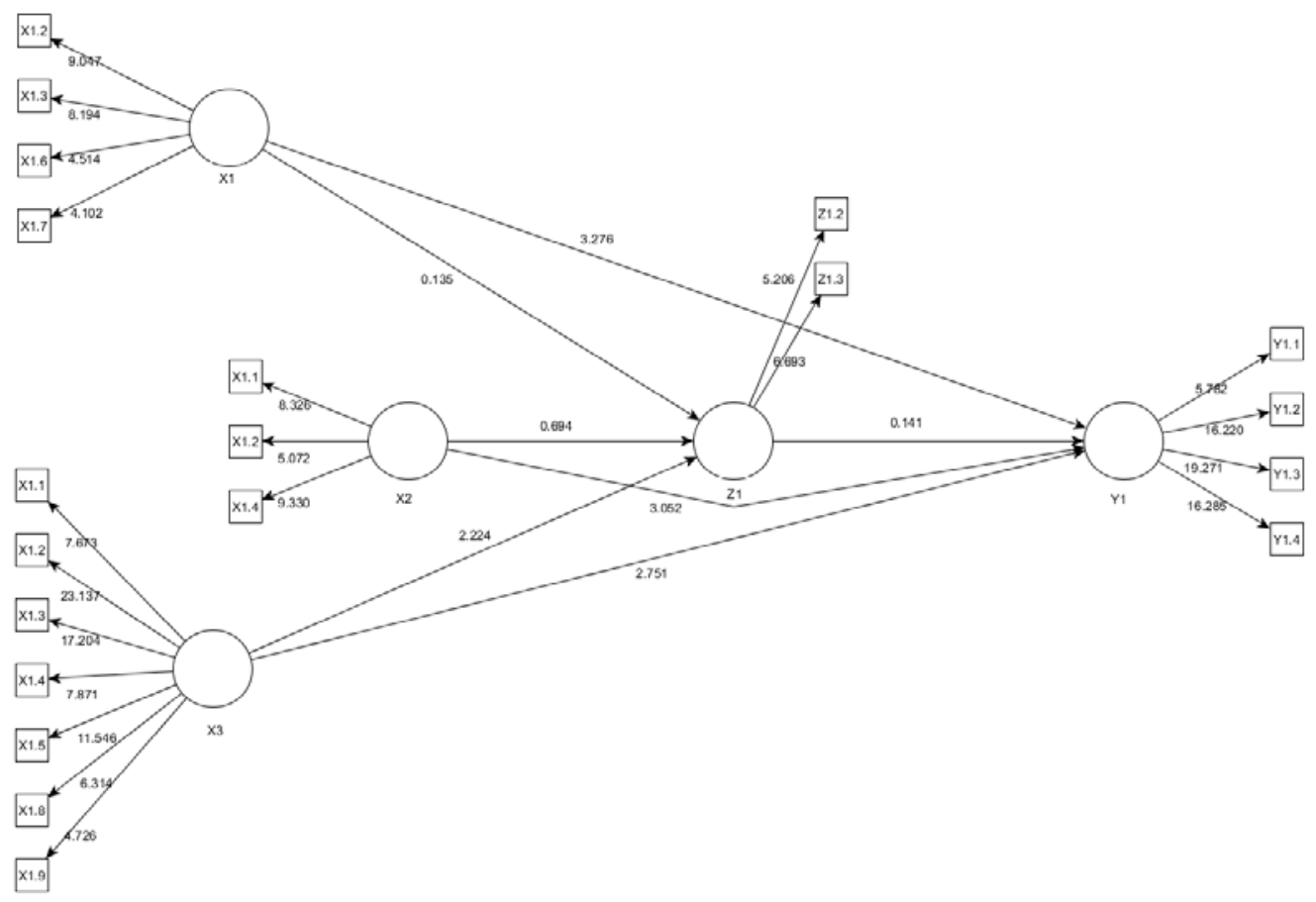

Gambar 3. Hasil Bootstrap PLS

\section{Aksesibilitas peternak terhadap sumberdaya dan pengaruhnya terhadap SDM}

Sumber Daya Manusia (SDM) peternak sapi perah dipengaruhi oleh sumber daya ekonomi, lingkungan, dan sosial sebesar 18,9\%, sedangkan sisanya sebesar 81,1\% dipengaruhi oleh faktor lain yang tidak terdapat di dalam model. Rayadi (2012) menyatakan bahwa peningkatan motivasi bekerja SDM menjadi lebih tinggi jika terdapat promosi jabatan, mutasi dan rotasi, serta demosi jabatan. Devita (2017) menyebutkan bahwa tiga hal yang sangat berpengaruh terhadap SDM adalah: a) faktor individu yang terdiri dari kemampuan, keterampilan, dan motivasi; b) daya dukung organisasi; dan c) dukungan manajemen.

Aksesibilitas peternak sapi perah terhadap sumber daya ekonomi berpengaruh terhadap SDM peternak secara negatif sebesar -0,021, namun pengaruh tersebut tidak signifikan karena nilai t statistik menunjukkan hasil 0,135. Nilai t statistik lebih rendah jika dibandingkan dengan nilai t tabel sebesar 1,653.

Aksesibilitas peternak sapi perah terhadap sumber daya lingkungan berpengaruh terhadap SDM peternak secara negatif sebesar -0,103, namun pengaruh tersebut tidak signifikan karena nilai t statistik menunjukkan hasil 0,694. Nilai t statistik lebih rendah jika dibandingkan dengan nilai t tabel sebesar 1,653.

Aksesibilitas peternak sapi perah terhadap sumber daya sosial berpengaruh terhadap SDM peternak secara negatif sebesar $-0,319$. Pengaruh tersebut adalah signifikan karena nilai t statistik menunjukkan hasil 2,224. Nilai t statistik tersebut lebih tinggi jika dibandingkan dengan nilai t tabel sebesar 1,653. 


\section{Aksesibilitas peternak terhadap sumberdaya dan pengaruhnya terhadap kelembagaan peternak sapi perah}

Kelembagaan peternak sapi perah dipengaruhi oleh sumber daya ekonomi, lingkungan, sosial dan SDM sebesar 20,6, sedangkan sisanya sebesar 79,4\% dipengaruhi oleh faktor lain yang tidak terdapat di dalam model. Laela (2010) menyatakan bahwa semakin tinggi rasio jumlah pengawas kelembagaan terhadap pelaksana organisasi, maka semakin efisien kinerja kelembagaan tersebut. Anantanyu et al. (2009) menyebutkan bahwa efektivitas kelembagaan petani secara langsung dipengaruhi oleh tingkat partisipasi petani di dalam kelembagaan, peran pihak luar, pendidikan formal petani, dan pengaruh kepemimpinan lokal.

Aksesibilitas peternak sapi perah terhadap sumber daya ekonomi berpengaruh terhadap kelembagaan peternak sapi perah secara positif sebesar 0,306. Pengaruh tersebut adalah signifikan karena nilai t statistik menunjukkan hasil 3,311. Nilai t statistik lebih tinggi jika dibandingkan dengan nilai t tabel sebesar 1,653.

Aksesibilitas peternak sapi perah terhadap sumber daya lingkungan berpengaruh terhadap kelembagaan peternak sapi perah secara negatif sebesar -0,266. Pengaruh tersebut adalah signifikan karena nilai t statistik menunjukkan hasil 3,027. Nilai t statistik lebih tinggi jika dibandingkan dengan nilai t tabel sebesar 1,653.

Aksesibilitas peternak sapi perah terhadap sumber daya sosial berpengaruh terhadap kelembagaan peternak sapi perah secara positif sebesar 0,287. Pengaruh tersebut adalah signifikan karena nilai t statistik menunjukkan hasil 2,717. Nilai t statistik lebih tinggi jika dibandingkan dengan nilai t tabel sebesar 1,653.

\section{Sumber daya manusia dan pengaruhnya terhadap kelembagaan peternak sapi perah}

Sumber daya manusia (SDM) peternak sapi perah berpengaruh terhadap kelembagaan peternak sapi perah secara positif sebesar 0,011, namun pengaruh tersebut tidak signifikan karena nilai t statistik menunjukkan hasil 0,141. Nilai t statistik lebih rendah jika dibandingkan dengan nilai t tabel sebesar 1,653. Wiyono dan Mustaruddin (2016) menyatakan bahwa aspek kelembagaan sangat berperan penting terhadap pembangunan. Widodo (2015) menyebutkan bahwa SDM mempunyai pengaruh terhadap kemampuan kerja pegawai sebesar 60,7\%, sedangkan sisanya dipengaruhi oleh faktorfaktor yang lain.

\section{KESIMPULAN}

Aksesibilitas peternak terhadap sumber daya ekonomi berpengaruh positif signifikan terhadap kelembagaan peternak sapi perah. Aksesibilitas peternak terhadap sumber daya lingkungan berpengaruh negatif signifikan terhadap kelembagaan peternak sapi perah. Aksesibilitas peternak terhadap sumber daya sosial berpengaruh negatif signifikan terhadap SDM peternak namun berpengaruh positif signifikan terhadap kelembagaan peternak sapi perah.

SDM Peternak dipengaruhi oleh sumber daya ekonomi, lingkungan, dan sosial sebesar 18,9\%, dan kelembagaan peternak sapi perah dipengaruhi oleh sumber daya ekonomi, lingkungan, sosial dan SDM peternak sapi perah sebesar 20,6\%. 


\section{UCAPAN TERIMA KASIH}

Naskah ini merupakan salah satu luaran hasil penelitian yang panjang dan berkelanjutan yang melibatkan berbagai pihak di dalamnya. Pihak-pihak tersebut layak mendapatkan apresisasi dari tim penulis. Tim penulis menyampaikan terimakasih kepada: a) LP2M (Lembaga Penelitian dan Pengabdian kepada Masyarakat) Universitas Jember; b) KeRis (Kelompok Riset) IFSLR (Integrated Farming System for Large Ruminant); c) KeRis Socioeconomic Aspect of Livestock Business and Product Technology (SOSEKTHT); d) PS Peternakan Fakultas Pertanian Universitas Jember; e) Kelompok Usaha Bersama (KUB) Tirtasari Kresna Gemilang; dan f) Peternak Sapi Perah di Kabupaten Malang Provinsi Jawa Timur.

\section{DAFTAR PUSTAKA}

Amam, Harsita PA. 2019. Efek domino performa kelembagaan, aspek risiko bisnis, dan pengembangan usaha terhadap SDM peternak sapi perah. Sains Peternakan. 17:5-11.

Amam, Jadmiko MW, Harsita PA, Poerwoko MS. 2019a. Model pengembangan usaha ternak sapi perah berdasarkan faktor aksesibilitas sumber daya. J Sain Peternakan Indones. 14:61-69.

Amam, Jadmiko MW, Harsita PA, Widodo N, Poerwoko MS. 2019b. Sumber daya internal peternak sapi perah dan pengaruhnya terhadap dinamika kelompok dan konteks kerentanan. J Ilmiah Peternakan Terpadu. 7:192-200.

Amam, Soetriono. 2019. Evaluasi performa kelembagaan peternak sapi perah berdasarkan aspek risiko bisnis dan pengembangan usaha. J Ilmu Teknologi Peternakan Tropis. 5:813.

Anantanyu S, Sumardjo, Slamet M, Tjitropranoto P. 2009. Faktor-faktor yang mempengaruhi efektivitas kelembagaan petani (kasus di Provinsi Jawa Tengah). J Penyuluhan. 5:81-91.

Devita M. 2017. Faktor-faktor yang mempengaruhi kinerja karyawan di Resturant Alpha Hotel Pekanbaru. JOM Fisip. 4:1-15.

Laela SF. 2010. Analisis faktor-faktor yang mempengaruhi kinerja organisasi pengelola zakat. Isalmic Finance Business Rev. 5:126-146.

Prasetyo AF, Awaludin A. 2016. Peran kelembagaan peternak dalam adopsi teknologi. J Ilmiah Inovasi. 1:133-137.

Rayadi. 2019. Faktor sumber daya manusia yang meningkatkan kinerja karyawan dan perusahaan di Kalbar. J Eksos. 8:114-119.

Siswoyo H, Setyono DJ, Fuah AM. 2013. Analisis kelembagaan dan peranannya terhadap pendapatan peternak di Kelompok Tani Simpay Tampomas Kabupaten Sumedang Provinsi Jawa Barat. J Ilmu Produksi Teknologi Hasil Peternakan. 1:172-178.

Wahyuni D. 2017. Penguatan kelembagaan petani menuju kesejahteraan petani. J Kesejahteraan Sosial. 10:9-12.

Widodo W. 2015. Pengaruh sumber daya manusia terhadap kemampuan kerja pegawai. J Tapis. 11:130-143.

Wiyono G. 2011. Merancang penelitian bisnis dengan alat analisis SPSS 17.0 \& Smart PLS 2.0. Yogyakarta (Indonesia): Unit Penerbit dan Percetakan STIM YKPN Yogyakarta. 